Síntese - Rev. de Filosofia

v. 37 N. 118 (2010): 227-241

\title{
O PRAZER DO TEXTO: PLATÃo, O CÍRCULO MAGNÉTICO E NÓS
}

(The pleasure of the text: Plato, the magnetic circle and ourselves)

Ivan Domingues*

Resumo: O artigo focaliza o tema do prazer do texto, explorando vários aspectos da leitura dos textos de filosofia e apoiando-se em três estudos considerados referência: $O$ prazer do texto, de Roland Barthes; o Ensaio sobre o gosto, de Montesquieu; e o fon, de Platão. A perspectiva é a do leitor, às voltas com as dificuldades de compreensão dos clássicos, portanto o último elo do contexto da difusão, e ele mesmo visto como co-criador do sentido.

Palavras-chave: Filosofia, texto, prazer, gosto, círculo magnético, autor, leitor.

Abstract: This article focuses on the subject of the pleasure of the text. It investigates several aspects of reading philosophical texts and is supported by three studies that are considered references: The pleasure of the text, by Roland Barthes; the Essay on taste, by Montesquieu; and Plato's Ion. It is written from the readers' perspective and their difficulties in understanding the classics. The reader is therefore seen as the last link in the diffusion context and as the co-creator of meaning.

Key Words: Philosophy, text, pleasure, taste, magnetic circle, Author, Reader.

\footnotetext{
* Professor do Departamento de Filosofia da Fafich/UFMG. Artigo submetido a avaliação em 10/05/2010 e aprovado para publicação 26/07/2010.
} 


\section{I - Introdução}

$\mathrm{D}$ esafiado pelo convite ${ }^{1}$, imaginei mais de um caminho para dar conta da minha tarefa, explorando a minha relação pessoal com a filosofia, na dupla condição de leitor dos clássicos da filosofia e de autor de obras filosóficas.

Inicialmente, eu pensei ater-me exclusivamente à minha condição de leitor de textos de filosofia e aos prazeres e desprazeres que a leitura dos clássicos e também dos recém-chegados, filósofos contemporâneos e colegas próximos, me vêm proporcionando ao longo desses já muitos anos de labor nos diferentes campos da filosofia. Todavia, logo depois de imaginar esse caminho, fui levado a abandoná-lo, pela simples razão de que as minhas atividades de leitura desde o início de minha formação estavam confundidas ou vinham juntas com as atividades de escritura - do simples trabalho escolar, passando pelos artigos, até os livros publicados. Então imaginei outro caminho, com dois trechos distintos: um consagrado à leitura; outro à escritura. Mas não deu certo ou, melhor, não gostei da ideia de separar e seqüenciar o que estava associado e vinha invariavelmente junto. A saída foi idealizar uma conferência que tratasse num só bloco, explorando as referências cruzadas e os pontos de tensionamento, minhas atividades de leitor e autor, com a esperança de compartilhar com vocês os altos e baixos dessa dupla experiência, cheia de alegrias e realizações, e também de dificuldades e frustrações, como é normal nessas circunstâncias e situações. O foco será então o prazer do texto, como me foi solicitado; porém, sem ignorar que o prazer é um sentimento que vem invariavelmente associado ao desprazer, o qual também será tratado ao longo de minhas considerações.

Além da experiência própria e da reflexão pessoal, procurei apoio textual para minhas considerações em três obras: 1 - O Prazer do texto, de Roland Barthes, provocado pelo título do colóquio, que é literalmente o mesmo; 2 - o Ensaio sobre o gosto, de Montesquieu; 3 - o Íon, ou sobre a Ilíada, de Platão. Depois digo o que eu tirei de cada um deles. Antes vou situar o contexto geral de minhas reflexões, dentro das coisas que venho fazendo habitualmente em meus cursos e em outras atividades, como palestras e colóquios.

Ao longo dos anos eu venho oferecendo aos alunos de graduação de Filosofia um curso optativo a que eu dei o nome de "Hermenêutica do texto

\footnotetext{
1 Este artigo é o resultado de uma conferência proferida na Universidade Federal da Bahia em agosto de 2009, por ocasião do Colóquio O prazer do texto, promovido pelo Departamento de Filosofia. Ao transformar as anotações em artigo, conservei o tom pessoal típico das comunicações orais, com a intenção de marcar-lhe a origem.
} 
filosófico". O curso é dividido em três partes. Na primeira, que é uma introdução geral, eu trabalho "A arte de ler e interpretar os textos - tentações e riscos", onde manejo os elementos contextuais, intencionais e textuais do trabalho de interpretação dos textos, focalizando três tentações e as maneiras de neutralizá-las, a saber: a tentação historicista, que põe o contexto no lugar do texto; a tentação subjetivista ou psicologista, que ao enfatizar os elementos intencionais vai atrás da alma do autor e coloca o autor no lugar da obra; a tentação filológica ou positivista, que focaliza as estruturas internas do texto e coloca a obra no lugar do contexto e do autor. Na segunda parte tematizo quatro métodos de leitura e interpretação dos textos filosóficos, com a ajuda de quatro intérpretes e quatro obras emblemáticas: 1 - o método genético-histórico: Starobinski leitor de Montaigne, em que focalizo os Ensaios do filósofo e a obra Montaigne em movimento do intérprete suíço, colocando em evidência o papel dos elementos contextuais e sendo eu mesmo levado em conta como mais um elo da cadeia, na condição de leitor do leitor e do autor; 2 - o método estrutural: Gueroult leitor de Descartes, onde focalizo as Meditações do filósofo e Descartes segundo a ordem das razões do intérprete francês, colocando em relevo o papel dos elementos textuais e levando em consideração, mais uma vez, minha dupla condição de leitor do leitor e do autor; 3 - o método linguístico-contextual: Baker leitor de Wittgenstein, onde eu focalizo as Investigações filosóficas do filósofo austríaco e $O$ método de Wittgenstein: aspectos negligenciados do intérprete americano, por muito tempo radicado em Oxford, até falecer, colocando em relevo os aspectos textuais, porém abrindo os elementos textuais ao exame pragmático contextual (contexto do uso dos vocábulos), e sendo eu mesmo incluído na cadeia interpretativa como um terceiro; 4 - o método fenomenológico-hermenêutico: Ricoeur leitor de Agostinho, em que focalizo várias obras de Agostinho consagradas ao problema do mal (Contra Secundinum, de Libero Arbitrio, Contra Manichaeus, etc.) e a obra do intérprete-filósofo francês $A$ simbólica do mal, sendo Ricoeur contrastado com os três outros na qualidade de filósofo (trata-se de um filósofo medindo forças com outro filósofo) e sendo eu mesmo duplamente considerado como leitor do autor e leitor do leitor. $\mathrm{Na}$ terceira parte do curso, que é a conclusão, tiro as consequências hermenêuticas ao avaliar as potencialidades e os limites dos quatro métodos, enfatizando a problemática mais ampla da produção do sentido e a questão da verdade ou falsidade das interpretações, e contrastando a solução da hermenêutica e a da lógica. Assim, o princípio da não-contradição, axial na lógica, mas em que a hermenêutica não reconhece o status de operador do sentido (pode haver sentidos contraditórios e um sentido dar passagem a seu oposto ou contrário), colocando em seu lugar os critérios da pertinência, da consistência e da abrangência das interpretações.

Pois bem, ao trabalhar esses problemas e os métodos, em mais de uma ocasião fui levado a considerar um conjunto de temas tradicionalmente conhecidos como afetos à crítica literária, a exemplo das questões do gê- 
nero literário da obra, do estilo do autor e do olhar do leitor. Assim, o gênero do tratado (Aristóteles) e do diálogo (Platão), bem como o estilo abstruso dos metafísicos segundo Hume e o estilo espontâneo e ensaístico de Montaigne (ensaio: testar uma ideia). E ainda, o papel do leitor na produção e realização do sentido, ao colocar em relevo um aspecto da obra e em recesso outro, no rastro dos trabalhos de Iser e Jauss na estética literária e de Gadamer e Ricoeur no terreno da filosofia (no caso dos dois últimos, estruturas pré-compreensivas relativas ao sujeito-leitor e mobilizadas no trabalho de leitura e interpretação dos textos).

Foi pensado nessas coisas, para melhor evidenciar o lugar e o papel do leitor, que imaginei um jogo dialético tomando como tema as tentações e os riscos na leitura e interpretação dos textos filosóficos. Ao situar o problema, venho explorando em meus cursos três situações. A primeira e mais dramática, evidenciando o perigo que ronda a leitura das obras, filosóficas ou literárias, é o leitor ficar doido de tanto ler, como o Quixote, que de tanto ler os romances de cavalaria e acreditar neles passou o resto de sua vida em busca de sua Dulcineia, acompanhado de seu fiel escudeiro Sancho, em meio a inimigos imaginários e lutando contra moinhos de vento (trata-se da ilusão do texto absoluto, à qual voltarei daqui a pouco). A segunda, mais banal e bastante comum, é o leitor se aferrar às suas opiniões ou se deixar levar pela opinião do autor, bem como a de outros leitores, oscilando entre a sua e as outras opiniões ou deixando a sua própria entre parênteses. O resultado é o império da dóxa ou do eu acho e suas duas grandes províncias: o dogmatismo da opinião pessoal, em que a opinião de outrem não conta nada; o relativismo da opinião, em que a opinião do outro conta tudo e a do sujeito não conta nada (trata-se de um bom exemplo do paradoxo das estruturas pré-compreensivas: o que fazer delas? e se elas discrepam?). A terceira situação é a do leitor impaciente e apressado, ávido de prazeres rápidos e de compreensão fácil das coisas, sem investimento pessoal e sem qualquer esforço intelectual (trata-se da esperteza do tolo, podendo dar lugar a leituras impressionistas e a verdadeiras interpretações selvagens). Assim, apressado e confiante, ele não terá dúvida, depois de assistir a páginas e mais páginas Riobaldo falando de taxonomia de mosquitos e outras esquisitices, no início do Grande Sertão: Veredas: simplesmente fecha o livro para nunca mais abrir. Então perderá a ocasião única de usufruir do prazer de uma obra-prima sem igual, um prazer todo especial que estava à mão ou a um passo de si, bastando vencer àquelas páginas iniciais e se acostumar ao dialeto do sertanejo dos Gerais. Era uma questão de paciência, e parece que Guimarães só pôs aquelas páginas para testar o leitor e deixar a obra em melhores companhias.

O sentido do jogo dialético, em realidade uma peça de retórica, é mostrar que o exercício da leitura e interpretação dos textos não é algo trivial e inocente, a ser conduzido espontânea e intuitivamente, mas é uma arte que 
requer cuidados especiais, em que o perigo está por toda a parte e o risco mora bem ao lado de cada um de nós. O perigo da tentação psicologista, ao derivar o sentido a partir da intenção do autor, em busca da fusão entre a alma do intérprete e a alma do autor, é o autor ficar no lugar da obra e o intérprete não ter o que analisar: a obra ela mesma em sua positividade. Já o perigo da tentação historicista, que enfatiza o contexto e computa o conjunto das opiniões, é o contexto ficar no lugar do texto, o sentido se estilhaçar no relativismo das opiniões e mais uma vez o intérprete não ter o que analisar: o texto ele mesmo em sua positividade. Por fim, o perigo da tentação estruturalista e também positivista, ao enfatizarem as estruturas e ocorrências internas da obra, em busca de seu arcabouço ou de sua gramática, sem qualquer remissão ao contexto, sem perguntar pela intenção do autor e sem considerar o olhar do leitor, é a obra se converter em referência única ou numa realidade autossubsistente (texto absoluto), ficando no lugar do autor e do leitor, cuja opinião não conta. Porém, ao fazêlo, o estruturalista e o positivista, sem que eles saibam, estarão subrepticiamente colocando o texto do intérprete no lugar do texto do autor, que é exatamente o segundo texto (o do intérprete) que irá revelar a sintaxe lógica ou a estrutura escondida do primeiro, e desde então, uma vez mais, o intérprete irá perder justamente aquilo que pretendia analisar, a saber: o texto ele mesmo em sua positividade. Quanto ao risco associado à esperteza do tolo ( $3^{a}$ situação), o perigo não poderia ser maior: simplesmente não há jogo possível, na falta do leitor e, por extensão, do intérprete, e por isso mesmo configura uma situação que fica fora do campo da hermenêutica do texto, devendo, pois, ser deixada de lado.

Estas são em suas grandes linhas o sentido geral de minhas reflexões neste campo da metodologia filosófica, o qual, ao meu modo, venho chamando de hermenêutica do texto filosófico. Outro nome possível é exegese filosófica, em paralelismo com outras formas de exegese, como a exegese bíblica, filológica ou jurídica. Trata-se de uma arte ou de uma técnica auxiliar, cujo eixo é a questão do sentido e tendo por propósito a sua decifração, sentido que circula por múltiplos canais, passando pela intenção do autor, pelos contextos vários, pela estrutura da obra e pelo olhar do intérprete. Estando em mais de um lugar ao mesmo tempo, o sentido desafiará a física e terá a estranha propriedade da ubiquidade; podendo ser erodido ou inflacionado, o sentido romperá com a estática e a constância do significado, ao se abrir ao devir e ao jogo da decomposição e da recomposição: tal será o sentido profundo da doutrina da composicionalidade do sentido, que coloca a hermenêutica no terreno da semântica, a meio caminho da linguística e da lógica. São estes em suma os principais resultados a que cheguei em meus trabalhos neste campo da filosofia e da metodologia filosófica, conferindo à hermenêutica o status de uma arte ou techne, a arte de ler e interpretar os textos, e como tal o status de uma técnica auxiliar a serviço dos métodos maiores da filosofia, tais como o método fenomenológico, dialético, transcendental, analítico e outros. 
Hoje, no Colóquio, depois de apresentar esse importante campo de minhas atividades, vou usar o segundo tempo da elocução para falar de outra coisa. O ponto que eu gostaria de considerar, ponto que eu vinha postergando por falta de tempo, mas que agora, desafiado pelo Colóquio, resolvi atacar de frente e oferecer a vocês os primeiros esboços de minhas reflexões pessoais, é justamente a relação entre a obra, o autor e o leitor visada do ponto de vista de sua fruição, que é o tema do Colóquio $O$ prazer do texto. É neste quadro que o apelo a Roland Barthes, a Montesquieu e a Platão faz sentido, como veremos.

\section{II - O prazer do texto, o encantamento da palavra poética e o juízo do gosto na filosofia}

O ponto que está em jogo, verdadeiro desafio intelectual, é pensar uma estética filosófica, capaz de aliar a estilística do autor e a composição da obra como gênero literário.

De Roland Barthes tomarei como fonte, conforme salientado no início, $O$ prazer do texto, ensaio famoso publicado em 1973 no campo da crítica literária e no rastro de uma obra anterior que causou grande impacto nos meios parisienses e norte-americanos, publicada em 1968 e intitulada $A$ morte do autor. A ideia comum aos dois ensaios que eu vou reter é a morte do autor como sujeito soberano e lugar do rei no processo de produção do sentido: sem o olhar onisciente do metaobservador que é testemunha ocular de tudo, como nos romances de Balzac, entra em cena e divide com ele o destino do sentido o leitor, cujo papel não é mais passivo, mas ativo, de sujeito cocriador do sentido, ao lado do autor e de outros leitores. Este ponto tornou-se um topos comum na chamada estética da recepção e foi levado a sério por filósofos de credos e escolas diferentes como Derrida, Foucault e Ricoeur.

De Montesquieu a fonte em que fui buscar apoio e que se revelou um verdadeiro manancial, ainda que inconclusivo para meus fins, foi o artigo que o barão de La Brède escreveu a pedido de d'Alembert para a Enciclopédia e nela publicada no volume VII em 1757. Ou seja: o Ensaio sobre o gosto, menos conhecido do que outras obras e republicado com uma ou outra modificação em suas Obras póstumas em 1783. Não vem ao caso, por falta de tempo, e não vale a pena, mesmo que eu tivesse todo o tempo, resumir o ensaio. O texto está disponível nas obras completas e seria, pois, ocioso reduplicá-lo. O que eu vou destacar é um conjunto de ideias de grande proveito para o estudioso da questão do gosto em diferentes terrenos da arte, que Montesquieu associa a diferentes tipos de prazer, distinguindo o gosto natural e o gosto adquirido e tomando o gosto como medida dos prazeres. Em se tratando das artes, em que é proeminente em sua 
criação e fruição o gosto adquirido e constantemente cultivado pela educação dos sentidos, Montesquieu dirá que “a arte dá as regras, e o gosto as exceções; o gosto descobre em quais ocasiões a arte deve submeter e em quais ela deve ser submetida". Tal foi o caso de Michelangelo, que conhecia como poucos as regras gerais e a techne da arquitetura, e também tinha "um conhecimento exato de tudo que pode dar prazer" e parecia ter "uma arte à parte para cada obra" ${ }^{2}$. Estas distinções sagazes me levaram a propor o meu próprio distinguo voltado para a hermenêutica como a arte de ler e interpretar os textos: por um lado, a arte e a techne filosófica, vinculada ao autor e à composição da obra e da qual a estética filosófica nos dá a regra geral; por outro lado, há o gosto, intimamente vinculado ao prazer, que é um sentimento associado ao autor (prazer de criar) e também ao leitor (prazer de fruir) e do qual a estética filosófica nos dá as razões particulares, a depender do meio (suporte) e da matéria empregada.

Sobre este ponto, o vínculo do prazer, do gosto e do sentimento é tal que Montesquieu, ao dar a definição do gosto, o coloca no centro da definição que aparece no início do ensaio: "A definição mais geral do gosto, sem considerar se ele é bom ou mau, justo ou não, é aquilo que nos liga a uma coisa pelo sentimento; o que não impede que ele possa se aplicar às coisas intelectuais, cujo conhecimento dá tanto prazer à nossa alma que ele era a única felicidade que certos filósofos poderiam compreender" ${ }^{\prime \prime}$. Sabendo o que é o gosto - um sentimento cuja fonte é o prazer, e uma medida cujo metron é a razão, uma razão intimamente associada e fusionada com o sentido - nada mais natural do que as três formas de prazer que a alma experiencia, tirando das suas produções um prazer que é todo seu: o prazer que ela tira de si mesma e do fundo da sua existência, dando vazão aos prazeres sublimes e altamente intelectuais; o prazer que ela tira de sua união com o corpo, dando lugar aos prazeres sensíveis, como os proporcionados pela pintura, pela dança e pelo canto aos nossos órgãos dos sentidos; e o prazer que ela tira das dobras de certas instituições, de certos usos e de certos hábitos, como na graça e no recato de uma mulher que, em vez de estampar o que sente, se contenta em sugerir o tesouro que ela esconde.

Segundo Montesquieu, "são os diferentes prazeres de nossa alma que formam o objeto do gosto, como o belo, o bom, o agradável, o ingênuo, o delicado, o terno, o gracioso, o não sei o quê, o nobre, o grande, o sublime, o majestoso, etc." ${ }^{4}$, cujas fontes estão em nós mesmos: sensíveis ou intelectuais, é a alma que os sente; quando a alma experiencia uma coisa associando-a à ideia da utilidade que ela pode ter para nós a alma dirá que a

\footnotetext{
${ }^{2}$ MONTESQUIEU, Essai sur le goût, p. 851.

${ }^{3}$ Id., p. 845 .

${ }^{4}$ MONTESQUIEU, op. cit., p. 845.
} 
coisa é boa; e se ela se limita a contemplá-la sem a ideia de utilidade dirá que a coisa é bela. Ao revelar a fonte do gosto no corpo e na alma, em seus dispositivos e em seus mecanismos, uns situados no cérebro ${ }^{5}$, outros nos nervos, por onde circulam os espíritos ${ }^{6}$, estaremos fornecendo as razões do gosto e ao mesmo tempo contribuindo para refiná-los e educá-los, quando ficará evidenciada a medida e a proporção dos prazeres que cada coisa dará aos homens. Tais serão - acrescento eu - as matérias-primas do juízo do gosto cujo objeto e ocasião de fruição as artes oferecerão em seus diferentes domínios, como a poesia, a pintura, a escultura, a música, a dança, as diferentes sortes de jogos de sociedade, a exemplo dos jogos de carta ou de azar. E entre seus parâmetros, tendo como critérios últimos o prazer e o seu duplo, o desprazer, estarão os prazeres da curiosidade, da ordem, da variedade, da simetria, do contraste, da surpresa, da delicadeza, da graça e da ingenuidade.

A assinalar que Montesquieu ao tratar destas coisas fala muito das artes e quase nada da filosofia. O leitor verá então que, quanto ao seu gosto pessoal, o filósofo não esconde sua preferência pela arte grega e da renascença, a ponto de colocar Michelangelo nas alturas, não escondendo sua mávontade para com o gótico francês e os virtuosi das óperas italianas. Da filosofia, do pouco que é dito, é revelado seu extremo desconforto com o estilo de Santo Agostinho, carregado de antíteses previsíveis e contínuas, cuja uniformidade o desagrada profundamente e tal é a falta de variedade que, segundo ele, basta a alguém ver a parte de uma frase para adivinhar a outra que irá segui-la na sequência ${ }^{7}$.

Tem mais, mas é melhor eu parar por aqui. A minha intenção é explorar o nexo entre prazer e gosto revelado por Montesquieu, bem como a ideia de prazeres intelectuais e prazeres sensíveis, e estender as análises para o campo da filosofia. Campo em que irá predominar os prazeres intelectuais e cuja circunscrição abrirá espaço para fornecer à estética filosófica o juízo que lhe seria próprio, cabendo à hermenêutica simplesmente constatá-lo ao vê-lo em ação nos diferentes campos da filosofia: trata-se do juízo do gosto, cuja pista ao juntar o sensível e o inteligível as línguas neolatinas perderam ao distinguir o sabor (prazer) do saber (conhecer), mas que o latim guardou no vocábulo sapere, que significa saber e também sabor, autorizando-nos a pensar que o sabor do texto está ligado ao saber e ao prazer que ele nos proporciona. Reconhecido isso, o próximo passo consistirá em forçar Montesquieu e estender o juízo do gosto, do terreno do particular que o barão de La Brède o encerrava, para o terreno do juízo compartilhado, se não universal ao menos geral e generalizável, um pouco como o sensus communis de Kant e o universal em situação dos hegelianos

${ }^{5}$ Id., p. 848.

${ }^{6}$ Ibid.

${ }^{7}$ MONTESQUIEU., op. cit., p. 847. 
e marxistas. Para tanto, será necessário considerar a terceira classe de prazer próprio da alma humana que Montesquieu aponta, mas sem a desenvolver em seu ensaio: justamente aquele que a alma tira das dobras dos usos e do fundo dos costumes.

Dito isso, passemos a Platão e ao anel magnético, o qual nos coloca diante de um outro problema relacionado com o tema do prazer do texto, mas visado de uma outra maneira e numa outra perspectiva: agora como uma coisa perigosa e associado à perda da liberdade e à alienação da mente. A metáfora do anel magnético, à qual Platão prefere a da cadeia magnética, aparece no diálogo Íon ou sobre a Ilíada que, segundo os estudiosos, deve ser incluído entre os escritos de juventude, ao lado do Hipias menor e da Apologia. O anel ou a cadeia recobre de fato, de um extremo a outro, o poeta, o intérprete (ou o rapsodo em linguagem platônica) e o público, tendo por contexto e mote as declamações nos teatros e em praças públicas dos poemas de Homero. Os personagens do diálogo são Sócrates e Íon, conhecido rapsodo e especialista da obra de Homero, a qual tanto declamava quanto comentava, fazendo uma interpretação alegórica, que já era conhecida dos gregos, e mesmo laudatória, que Íon e Sócrates consideravam "inspirada" e creditavam a fonte de inspiração às musas. Como em outros diálogos, Platão não esconde sua má vontade com os poetas em geral e Homero em particular. No Banquete são conhecidas as passagens onde ele insulta os poetas. Na República ele expulsa os poetas da cidade ideal. No Fedro, ao estabelecer a hierarquia das almas, ele coloca a dos poetas em sexto lugar, acima da alma dos artesãos. No Íon o poeta e o rapsodo aparecerão como marionetes e instrumentos dos deuses. Em seguida vou tentar reconstruir o raciocínio desenvolvido por Sócrates até chegar ao anel magnético, de que ele se serve para pensar a relação entre a musa, o poeta, o intérprete e o ouvinte, e que será usada ao meu modo para pensar a situação da filosofia, colocando o filósofo no lugar do poeta.

O ponto de partida do diálogo é o encontro de Sócrates com Íon em algum lugar de Atenas, tendo por contexto imediatamente anterior as festas consagradas a Esculápio em Epidauro, de onde regressava Íon tendo delas participado como rapsodo e arrebatado vários prêmios. Sócrates congratula-se com Íon e diz que o feito dele era digno de inveja, evidenciando que ele devia conhecer a fundo os pensamentos de Homero e não somente as palavras e os versos. Íon, sem falsa modéstia, aquiesce: “(...) acho que sou - responde ele - , dentre os homens quem fala de modo mais belo sobre Homero, porque nem Metrodoro de Lâmpsaco, nem Estesímbroto de Tasos, nem Glauco, nem nenhum outro dos que até hoje existiram foi capaz de falar assim muitos e belos pensamentos a respeito de Homero como eu" 8 .

\footnotetext{
${ }^{8}$ PLATÃO, Íon, 530, p. 23. Daqui para frente, nas paráfrases e remissões contextuais, só indicarei os parágrafos da edição brasileira consultada.
} 
De fato Íon só conhece Homero e só quer saber de Homero. Não conhece nada de Hesíodo, nem de Arquíloco ${ }^{9}$. Se alguém lhe pergunta alguma coisa sobre outro poeta, não saberá o que dizer e logo perderá o interesse na conversação, morrendo de vontade de dormir. Em contraste, se alguém menciona o nome de Homero, tudo muda, imediatamente fica "acordado", presta "atenção" no que é dito e um monte de ideias lhe vem à mente ${ }^{10}$.

Sócrates escuta atento e passa à ofensiva, explorando as revelações explícitas e um conjunto de subentendidos, com a intenção de desestabilizar o interlocutor. O raciocínio é o seguinte: a supor a existência da arte da poesia em geral, aquilo que Íon é capaz de fazer e tão bem, porém restrito a Homero, em realidade não é uma arte e não provém da arte, mas tratase de outra coisa. Se fosse arte, Íon estaria em condições de falar de todos os outros poetas sem exceção. Todavia, reconhece Ílon, este não é o caso: ele só conhece Homero e só quer saber de Homero ${ }^{11}$.

A explicação que dá Sócrates a esse estado de coisas, capaz de reconhecer aquilo que há de prodigioso e de excesso nas performances de Íon paralelamente a platitude e a falta que a acompanham, revelando a total incapacidade do rapsodo de compreender o que faz e é capaz de fazer, aparece em 533-534 onde avança a hipótese do círculo magnético. Ou seja: o dom maravilhoso de que Íon é o portador provém de uma "força divina", cuja ação arrebatadora sobre o rapsodo e cuja capacidade de atrair e encantar os ouvintes Sócrates compara com a pedra imã, ao aludir à pedra que Eurípedes chamou de magnética (Magnétis lízos) e que é comumente chamada de Heracléia. Como se sabe, tal pedra em contato com o ferro transmite o magnetismo ao metal e este passa a ter o poder de atrair outros pedaços de ferro, constituindo uma imensa cadeia magnética, funcionando cada pedaço como elo ou anel, e dependendo a força do conjunto daquele pedaço magnetizado. A mesma coisa ocorreria, segundo Sócrates, com o rapsodo, o poeta e o ouvinte, aos quais é preciso acrescentar a Musa a que o poeta recorre para explicar a beleza de seus versos e o poder encantatório de suas palavras. Metaforizando, a pedra imã ou o magneto será a Musa, que transmite seu poder de atrair as mentes e os ouvidos ao poeta, o poeta o retransmite ao rapsodo e este à audiência, formando assim uma cadeia. Tal cadeia - acrescento eu — poderá ser chamada de cadeia magnética, se prevalece a ideia de justaposição e de encadeamento linear, ou então de círculo magnético, se prevalece a ideia de inclusão e de encapsulamento circular (anel de anéis ou círculo de círculo).

Para os fins do argumento, pouco importa o nome e a figura; o essencial é entender o magnetismo que circunda e acompanha a obra e a palavra do

${ }^{9}$ Id., 531

10 Id., 532.

11 PLATÃO, op. cit., 532. 
poeta, magnetismo que é um poder não do poeta e menos ainda do rapsodo, mas da musa ou de um deus. Tal poder divino e força arrebatadora o próprio poeta reconhece não pertencer a ele, ao dizer não só que foi inspirado pelas musas e estava possuído por elas quando compôs seus versos, mas que estava fora de si e do pleno poder das suas faculdades conscientes e racionais no momento em que os escreveu ou os declamou. Tomando essa ideia a sério, Sócrates compara o surto criativo do poeta com o transporte báquico das bacantes que, quando possuídas pelo furor divino, bebem mel e leite dos rios, e fazem coisas que não costumam fazer quando estão no estado de vigília e em posse da razão. Da mesma forma o poeta, pode-se dizer, o qual segundo o filósofo "não pode poetar até que se torne inspirado e fora de si, e a razão não esteja mais presente nele. Até conquistar tal coisa, todo homem é incapaz de poetar e proferir oráculos"12.

E mais: a força e o encantamento da poesia devem, pois, ser creditados ao deus e tomados como um privilégio divino. É como se o deus tivesse possuído o poeta, privando-o da razão e tomando-o como seu servidor, a exemplo do que ocorre com os profetas e adivinhos inspirados ${ }^{13}$. E ainda: não só é possuído o poeta, mas também o rapsodo que, transportado pelo entusiasmo arrebatador, sai fora de si e se deixa levar pelas mãos das musas e dos deuses, pondo em contato o poeta e o público, e deixando o ouvinte eletrizado, como se estivesse diante de Ulisses em pessoa a disparar suas flechas ou ante a Aquiles a se lançar sobre Heitor ${ }^{14}$. A exemplo do poeta, o rapsodo não é dono de sua razão, nem o senhor de sua arte, cujo magnetismo e capacidade de atrair os ouvidos e as mentes devem ser atribuídos aos deuses. E enfim: a própria audiência será uma presa fácil do mesmo furor divino e se mostrará como o último elo da cadeia magnética, disposta a rir e a chorar - acrescento eu - segundo a cadência e o ritmo do rapsodo, como se estivesse diante de um deus em pessoa e disposta a pagar caro pelo privilégio, imaginando estar com os pés em Ítaca ou em Troia ${ }^{15}$.

Resumindo, com a entrada do público, fica então fechado o círculo magnético. Primeiro, há a pedra imã: a musa. Depois, o primeiro anel ou elo: o poeta. Em seguida: o rapsodo ou o intérprete. Por último: o ouvinte ou a audiência. Na origem do magnetismo está o magneto, cujo poder de atração é passado a cada um dos intermediários e cuja ação conjunta, como se fosse uma cadeia única, fica na dependência da pedra famosa. Ao fim e ao cabo, é a própria divindade, através de todos os intermediários, que arrasta a audiência, fazendo passar a força magnética de um indivíduo a outro. Num extremo está a musa e os poetas; noutro, o rapsodo e o ouvin-

\footnotetext{
${ }^{12}$ PLATÃO, op. cit., 534.

${ }^{13}$ Id., 534.

${ }^{14}$ Id., 535

${ }^{15}$ Ibid. - contexto e sentido modificados.
} 
te. A situação de Íon, como rapsodo, fica esclarecida inclusive para ele próprio no curso da conversação com Sócrates, não sem uma ponta de ambiguidade (pois Íon gostou de ser comparado com um ente divino): como a maioria dos rapsodos, também ele, Íon, estava possuído por Homero, e sua maestria em interpretar o aedo não era devido a uma arte ou a algo que se pudesse explicar racionalmente, mas a um dom divino, como se estivesse sob a influência de uma possessão ou de um delírio incontrolado ${ }^{16}$.

\section{III - Conclusão}

A conclusão que vou tirar dessas belas e densas passagens do Íon, das quais ninguém sabe fazer a triagem exata daquilo que pertence a Platão e daquilo que pertence a Sócrates, deixando a ideia de autoria em situação de grande precariedade, a conclusão que delas vou tirar - repito - me colocará longe dos poetas e na companhia dos filósofos. A pressuposição de Sócrates é que o filósofo, ao consultar seu daimon interior e seguir o caminho do logos, guardará intacta sua capacidade de pensar com autonomia e liberdade. Diferentemente do poeta, o filósofo não se deixa levar pela força arrebatadora das belas palavras e não corre o risco de se ver preso no anel magnético que liga a musa, o poeta, o rapsodo e o ouvinte. Pois, diz Platão com Sócrates, ao se referir à razão: enquanto conserva esta capacidade ou faculdade, "todo homem é incapaz de poetar"17 e criar uma obra poética, obra cuja matéria-prima é o sentimento e cujo veículo capaz de vencer todas as distâncias é o transporte báquico.

Na sequência da exposição, terminando minhas reflexões, vou mostrar que o mesmo perigo apontado por Platão ao se referir ao anel magnético da poesia, círculo que impede o poeta e o rapsodo de pensar, pode ser estendido à filosofia. Então, teremos duas situações rigorosamente paralelas: a situação do filósofo que, ao se entregar ao magnetismo da razão, não conseguirá pensar; a situação do intérprete que, possuído pelo filósofo, não consegue mais pensar. Um pouco foi o que viu Wittgenstein ao falar do enfeitiçamento das palavras, que nos ata a elas como se fossem um guizo e nos deixa preso a elas, sem movimento e sem liberdade, acreditando em quimeras, em essências e em quididades. Um pouco disso foi também o que viu Bacon ao falar das várias classes de ídolos, alguns provenientes da linguagem, outros do próprio pensamento.

Ao tocar nesses pontos, eu gostaria de acrescentar duas situações opostas, associadas à questão do gosto e, por extensão, do prazer do texto.

${ }^{16}$ PLATÃO, op. cit., 535 - 536.

${ }^{17}$ Id., 534. 
Primeiro, a sedução das belas palavras, cujo círculo magnético se estendeu à filosofia francesa, que até recentemente levou muitos filósofos e estudiosos da filosofia a pensar a filosofia como se fosse uma extensão da literatura. Foi o que aconteceu com Bergson, Merleau-Ponty, Sartre e Foucault, para os quais muitas vezes mais vale um belo pensamento ou uma frase de efeito com suas tournures bem construídas, ainda que falsos e infundados, do que a mais chapada e anódina das verdades. Para nos convencer disso, basta folhear a História da loucura e As palavras e as coisas - obras que eu muito admiro, aliás.

Segundo, a sedução do pensamento hermético e da linguagem cifrada, cujo círculo magnético com o poder de atrair multidões se estendeu à filosofia alemã e recentemente atingiu segmentos importantes da filosofia francesa. No caso dos alemães, o encantamento do hermetismo levou a alturas inimagináveis o gosto pela filosofia abstrusa de que falava Hume, como no idealismo alemão, que no meu modo de ver sentenciou de morte o pensamento alemão, não sem antes dar-lhe a aura de prestígio e profundidade. Situação alterada com a segunda guerra, após a grande diáspora da intelligentsia alemã para os Estados Unidos, e simplesmente invertida depois, quando os alemães, indefesos e seduzidos, foram abandonados às investidas tardias da filosofia analítica anglo-americana. No caso dos franceses, numa linha diferente, mas não menos hermética e cifrada, uma vez passado o tempo da moda estruturalista, foi a vez do pós-modernismo e do pensamento da desconstrução. Então descobrimos que o famoso bom gosto e o proverbial gosto dos franceses pela clareza estão vivendo tempos difíceis no hexágono.

No século XVIII, o francês Béat-Louis de Muralt assim descreveu o estilo de pensamento de seus compatriotas, marcado por uma retórica poderosa e pela esteticização: “O estilo, independentemente do que ele exprima, é um assunto importante na França. Em outros países, os pensamentos dão origem às expressões (...). Aqui, é o inverso; frequentemente, são as expressões que dão origem ao pensamento"18. Quanto ao estilo dos pós-moder-

\footnotetext{
18 A citação de Muralt foi tirada do historiador inglês Tony Judt, que publicou um importante livro sobre a intelligentsia francesa, intitulado Passado imperfeito - Um olhar crítico sobre a intelectualidade francesa no pós-guerra, cuja tradução portuguesa saiu no Brasil em 2007 pela Editora Nova Fronteira. A citação aparece na p. 338 e se refere à obra de Muralt Lettres sur les Anglois et sur les François, originariamente publicada em 1728 e reeditada em 1933, p. 261. Judt é inglês radicado nos EUA e grande especialista na história francesa contemporânea. Um pouco antes de citar Muralt, ele comenta uma passagem extremamente irônica do britânico Dr. Johnson - jornalista, poeta, crítico literário e ensaísta muito influente no Reino Unido - que 50 anos depois de Muralt assim descreve os franceses em comparação com a atitude dos ingleses nas discussões e matérias do pensamento: "Um francês tem que falar sempre, quer ele entenda do assunto, quer não; um inglês se contenta em não dizer uma palavra quando não tem nada a dizer" (p. 338).
} 
nos e descontrucionistas, com suas maneiras e obscuridades, parece que é o inverso que ocorre, ao se chegar à curva do séc. XX: meras expressões sem pensamento, para decepção e preocupação minhas, eu que nunca escondi minha admiração pela clareza e a elegância francesas.

Agora, para terminar, alguma coisa de minha experiência pessoal.

Primeiro, a questão do autor: Chico Buarque disse há pouco tempo, no Festival Literário de Paraty e para desagrado de muita gente, que ele detestava o ofício de escritor, reconhecendo que para escrever alguma coisa ele tem que ler e ler e ler muito. Um pouco esta é a situação do filósofo e a minha própria, porém não compartilho do ódio de Chico Buarque ao ofício das letras. Não compartilho, ainda que eu saiba que a filosofia jamais poderá concorrer em charme com a literatura, mesmo que um dia lhe seja reservado exclusivamente o prêmio Nobel, e ainda que eu conceda de bom grado que mais de um filósofo, além da força do gênio do pensamento, esbanjou o talento de escritor: Platão, Descartes, Nietzsche e o próprio Bergson, que recebeu o prêmio Nobel de literatura. Do autor, além do mais, eu afirmaria não a sua morte, como o fez Roland Barthes, mas a sua reinvenção e o compartilhamento das suas funções com o leitor, como bem o mostra o caso de Parfit, de Oxford, que divide as alegrias e as tristezas do ofício de escrever filosofia com seus amigos e alunos: assim, ele vem há anos nos seus cursos e na Internet discutindo seu último livro até hoje não publicado, tendo inclusive mudado o título de Climbing Mountains [Subir Montanhas] para On what Matters [Sobre o que importa].

Do exegeta ou rapsodo eu observaria duas coisas. A primeira: minha condição de ex-marxista, ex-hegeliano e ex-dialético ou quase: durante anos eu me vi às voltas com o anel magnético do discurso inspirado, um anel ideológico poderoso que me colocava em relação direta com as musas do proletariado e às voltas com os encantos do pensamento único, que me deixava nas bordas do dogmatismo, mas exposto às querelas das igrejas, das heresias e das seitas, entregue ao dogmatismo múltiplo e ao seu antípoda: o relativismo. Hoje, tendo vencido a tentação do dogmatismo, procuro resistir aos males do relativismo, mas não é fácil fazer isso no ambiente da filosofia contemporânea. A segunda coisa: a relação tensa e difícil do filósofo e do exegeta. Além de mau historiador, o filósofo é mau exegeta e detesta ver seu trabalho esquadrinhado e trivializado pelo comentador. Tal é também a situação do escritor. Uma vez, dividindo uma mesa com Silviano Santiago no Festival de Inverno de Diamantina, escutei dele uma comparação que desestabilizou profundamente certas certezas que eu cultivava em meus cursos de Hermenêutica: a comparação era com o andaime, as grades e as ferramentas que o escritor usa na construção da obra, envolvendo muitas vezes longas e pacientes pesquisas. Anotados em mais de um lugar, os resultados serão usados aqui e ali, e muitas vezes não serão usados nunca, até que um belo dia a obra fica pronta e ele pode jogar 
fora o andaime, para melhor apreciar a obra e deixá-la na companhia de seus leitores. Aí vem o crítico ou exegeta e teima em voltar com tudo e mais alguma coisa daquilo que ele não quer ver e tinha descartado... Realmente não dá para ajustar as duas perspectivas, um querendo deixar intacto o anel magnético, o outro querendo quebrá-lo para adentrar na obra.

Do filósofo, enfim, para terminar, digo que há bem um anel magnético que protege sua obra das investidas do intérprete e do olhar indiscreto do leitor: trata-se do anel magnético dos clássicos, fonte permanente de atração que a obra desperta, arrastando atrás de si uma multidão de leitores, e ao mesmo tempo protegendo-a e fazendo com que ela resista - a nós e ao tempo. Um pouco como Kant ao ler Rousseau: primeiro, com o coração acelerado, depois com a cabeça fria, quando descobriu que o filósofo está lá e resiste... Ou eu mesmo ao ler o Ser e tempo de Heidegger, quase que de um só fôlego, como se lê um romance, admirado e totalmente entregue, para depois descobrir que o autor da obra admirada a repudiou, mas sem me convencer como leitor: então, contra o autor, eu decidi ficar com a obra, e contra o Heidegger II, com seu palavrório e hermetismo, prefiro o Heidegger I. Como no caso de Wittgenstein, o cristal puro está no começo, não no fim, e não foi polido nem erodido pelo tempo.

\section{Referências bibliográficas}

BARTHES, R. Le plaisir du texte. Paris: Seuil, 1982.

JUDT, T. Passado imperfeito - Um olhar crítico sobre a intelectualidade francesa no pós-guerra. Rio de Janeiro: Nova Fronteira, 2007.

MONTESQUIEU. Essai sur le goût, in: Oeuvres complètes. Paris: Seuil, 1964.

PLATÃO. Íon, in: Sobre a inspiração poética (Íon) \& Sobre a mentira (Hípias Menor). Porto Alegre: L\&PM, 2007.

Endereço do Autor:

Rua Alvarenga Peixoto, 435 / Apto. 702 - Lourdes

30180-129 Belo Horizonte - MG

e-mail: domingues.ivan3@gmail.com 
